www.volsu.ru

DOI: http://doi.org/10.15688/nav.jvolsu.2017.1.5

UDC 930.26(470+571):726

LBC 63.48(2)-427.1

\title{
MORPHOLOGY OF CHILD BURIALS OF EARLY NOMADS IN THE LOWER VOLGA REGION (BASED ON MATERIALS OF THE BURIAL MOUNDS OF EARLY SARMATIAN TIME) ${ }^{1}$
}

\author{
Mariya A. Balabanova \\ Volgograd State University, Volgograd, Russian Federation
}

\begin{abstract}
The article is devoted to morphology of child burials of the Early Sarmatian time in the Lower Volga region, which have been studied on the basis of five burial mounds -Berezhnovka, Kalinovka, Kovalevka, Pervomaysky, Peregruznoe I. During the analysis the following age groups of children have been studied: 04 years; 5-9 years; $10-14$ years (from 132 child burials). The age was specified within the framework of these three age groups in all cases. Besides, the infant burials (from newborns to one year old) were studied both separately and in their age group ( $0-4$ years).

The results show that there was a high level of child and infant mortality rate in all burial mounds. The mortality of children depended on age and decreased from the first age group (0-4 years) to the last one (1014 years).

The peculiarities of the funeral rite and its content in the burials of things were also directly related to lifespan and the possible status of the deceased child, which was increasing with aging. The research results show that the presence of burial equipment in child burials was less required than, perhaps, in burials of adults or adolescents which were noticeably distinguished by the more frequent presence of burial equipment and not found in the burials of children of younger groups.

The conducted research allows concluding that children were involved in everyday life in Early Sarmatian society, and their role increased with aging. It apparently reflected the utilitarian attitude to the children, as value of children was defined by their contribution to the family welfare. That's why in the period of famine, which was not rare in nomadic societies, young children died first.

Key words: children, adolescents, mortality table, burial rite, age cohort, child mortality, socialization, burial equipment.

Citation. Balabanova M.A., 2017. Morphology of Child Burials of Early Nomads in the Lower Volga Region (Based on Materials of the Burial Mounds of Early Sarmatian Time). The Lower Volga Archaeological Bulletin, vol. 16, no. 1, pp. 62-82.
\end{abstract}

УДК 930.26(470+571):726

ББК 63.48(2)-427.1

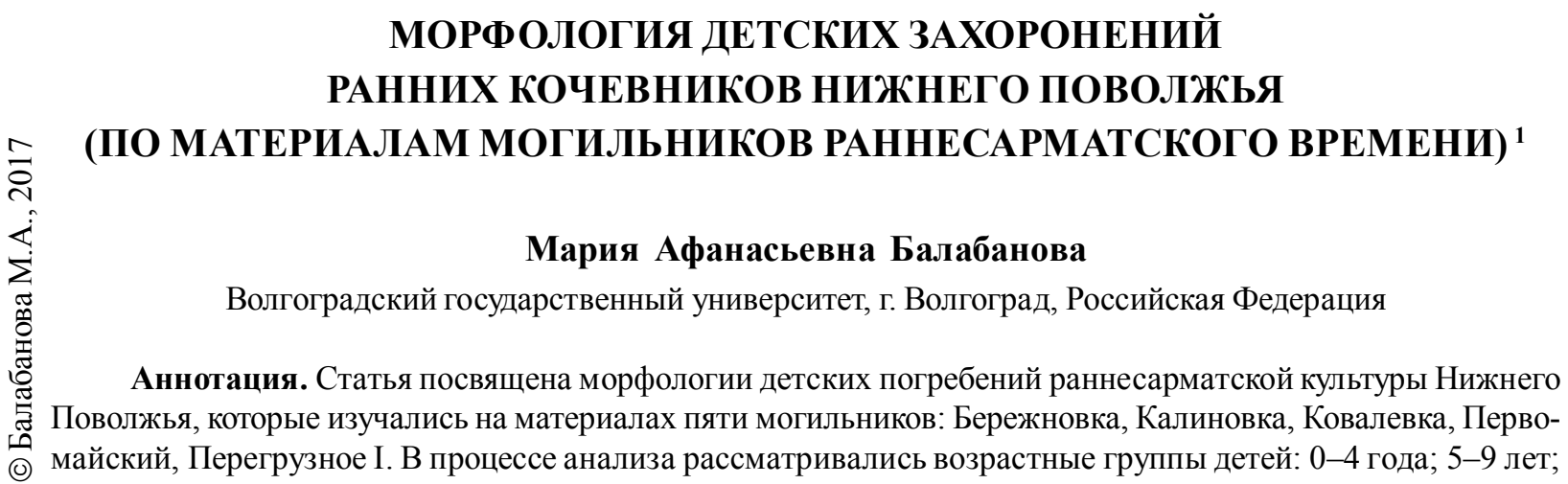


10-14 лет из 132 детских захоронений. Во всех случаях был детализирован возраст в рамках этих трех возрастных групп. Кроме этого, погребения детей младенческого возраста (от новорожденности до 1 года) рассматривались как отдельно, так и в группе детей от 0-4 лет.

Результаты исследования показали, что во всех могильниках был высокий уровень детской и младенческой смертности. Смертность детей зависела от возраста, и она падала от первой возрастной группы (04 года) к последней (10-14 лет).

Особенности погребального обряда, содержание в погребениях вещей также напрямую были связаны с количеством прожитых лет и возможным статусом умершего ребенка, который повышался по мере взросления. Результаты исследования показали, что снабжение детей сопроводительными предметами при погребении было, видимо, менее обязательным, чем при погребении взрослых и подростков, которые заметно выделяются более частым присутствием предметов сопроводительного инвентаря, не встреченных в захоронениях детей младших групп. На основе проведенного исследования можно с достаточной уверенностью говорить о том, что дети в раннесарматском обществе рано включались в повседневную жизнь, и роль их повышалась с увеличением календарного возраста. Это напрямую было связано с утилитарным отношением к детям, так как дети в семье начинали работать с самого раннего возраста. В периоды голода, что не было редкостью в кочевых обществах, маленькие дети умирали первыми.

Ключевые слова: дети, подростки, таблица смертности, погребальный обряд, возрастная когорта, детская смертность, социализация, погребальный инвентарь.

Цитирование. Балабанова М. А., 2017. Морфология детских захоронений ранних кочевников Нижнего Поволжья (по материалам могильников раннесарматского времени) // Нижневолжский археологический вестник. Т. 16, № 1. С. 62-82.

\section{Введение}

Усилиями многих археологов погребальная обрядность племен, населявших Нижнее Поволжье в раннесарматскую эпоху (II-I вв. до н.э.), исследована достаточно полно [Скрипкин, 1997; Сергацков, 2000; Клепиков, 2002; Балабанова и др., 2015 и др.]. В этих работах большое внимание уделялось погребальному обряду взрослой части населения. Детская погребальная обрядность как самостоятельный объект исследования рассматривалась В.М. Клепиковым только в главе коллективной монографии «Погребальная обрядность в раннесарматское время» [Балабанова и др., 2015]. Он изучил 144 детских костяка, из которых 104 на момент смерти находились в возрасте от младенчества до 9 лет; 20 - в возрасте 10-15 лет и у 20 костяков возраст не был определен. Детские захоронения в данной выборке представлены как индивидуальными могилами (75 детей), так и коллективными (66 детей). Наибольшее количество индивидуальных захоронений располагалось на периферии кургана, и только пять детских погребений - в центральной его части. Еще 20 детей находились в центральных коллективных могилах вместе с взрослыми.
По типам могильных конструкций детские захоронения распределялись следующим образом: в прямоугольных ямах, узких и широких (включая и ямы с заплечиками), было похоронено более трети погребенных - 53 костяка; в подбоях - 64 ребенка, включая специально сооруженные подбои-ниши для детей в прямоугольных ямах; в катакомбах находилось 6 детей, в остальных случаях могильные ямы не были прослежены. Определенная часть детей встречались в гробах решетчатой конструкции (20 случаев) и в колодах (2 peбенка), хотя более традиционным остается захоронение в погребальной камере под перекрытием на подстилке.

Что касается цветового сопровождения захоронений детей, то цветные минералы: мел, реальгар, охра, сера встречается единично. Как и в погребениях взрослых, из напутственной пищи присутствуют кости овцы (в 44 погребениях). Часть туши - преимущественно передняя нога овцы с лопаткой или без нее, хотя есть и исключение в виде целой тушки барана - лежит либо в ногах, либо в головах детей. Есть случаи, когда кости овцы находились слева, справа, во входной яме или сразу в нескольких местах от погребенного ребенка. Кроме этого, в двух случаях найдены альчики овцы, что не характерно 
для взрослых захоронений [Балабанова и др., 2015$, c. 31,32$]$.

Из вещевого материала в детских могилах чаще всего встречается керамика, как лепная, так и круговая. Она найдена и у детей до 9 лет, и у подростков. Расположение керамики традиционное для всей раннесарматской культуры - в ногах, в головах, либо сразу и в ногах, и в головах, а также слева и справа и во входной яме, что довольно редко встречается. Оружие встречается редко - в четырех случаях найдены мечи, в семи - наконечники стрел и, что особенно любопытно, - в двух случаях у ребенка и подростка (Тары II, кург. 10, погр. 3 и 8) найдено по комплекту из меча и стрел, свидетельствующему об определенном социальном статусе. Следует отметить еще одно обстоятельство: во всех четырех случаях нахождения меча в детских погребениях дети и подростки лежали головой в северный сектор.

Категорию бытовых предметов, которые наиболее часто встречаются в детских могилах, составляют небольшие железные ножи, обычно сопровождающие мясную пищу, на втором месте - пряслица, железное шило. Ритуальные предметы представлены костяными ложечками, каменными плитками, отщепами и раковинами, частота встречаемости которых низка. Рядом с пятью детскими костяками найдены фрагменты зеркал. Из номенклатуры украшений представлены бусы, особенно у маленьких детей, изредка - серьги, перстни, браслеты, фибулы и даже гривны [Балабанова и др., 2015, с. 31, 32].

Таким образом, изучение детской раннесарматской погребальной обрядности нижневолжских могильников демонстрирует общую ритуальную традицию, характерную для этого времени и этой культуры.

Еще одна работа по детским погребениям кочевников раннесарматского времени с использованием материалов могильников Южного Приуралья недавно была опубликована Н.А. Берсеневой в соавторстве с А.Х. Гильмитдиновой [Берсенева, Гильмитдинова, 2013]. Ими изучено более 100 детских и подростковых захоронений. В результате исследования они пришли к следующим выводам:

1) дети погребались в могильниках по такому же обряду, что и взрослые;
2) детей в могилах сопровождал более скудный инвентарь, чем взрослых;

3) наиболее частыми находками в прохоровских детских погребениях разных возрастных групп являются кости животных, сосуды и украшения;

4) детям часто сооружались глубокие и сложные по устройству могилы;

5) большая часть детских захоронений периферийной локализации в кургане;

6) в качестве заупокойной пищи в погребениях детей встречаются только кости мелкого рогатого скота;

7) реконструкция социальной жизни прохоровских детей позволяет выделить две социально значимые возрастные группы: от 0 до 5 и от 5 до 18 лет:

- первая группа характеризуется преобладанием гендерно-нейтрального сопроводительного инвентаря;

- вторая группа отражает процесс гендерной и возрастной социализации.

Как считают авторы статьи, по-видимому, гендерная дифференциальная социализация у раннесарматских племен Южного Приуралья начиналась где-то в возрасте около 5 лет, что вполне соотносится с современными социологическими исследованиями, которые определяют порог начала гендерной социализации в 3 года. Именно в этом возрасте дети начинают идентифицировать себя с определенным гендером [Берсенева, Гильмитдинова, 2013, с. 42].

Материал исследованных раннесарматских погребений Южного Приуралья показывает, что более половины детей старше 5-летнего возраста сопровождались гендерно-стереотипными наборами (56\%), но в возрастной группе от 5 до 18 лет отсутствует динамика увеличения доли гендерно-стереотипных наборов от младших возрастов к старшим, хотя их физические возможности очевидны [Берсенева, Гильмитдинова, 2013, с. 43].

Таким образом, результаты вышеприведенных исследований показали возможности использования характеристик погребального обряда детской части населения для реконструкции как детской субкультуры, отраженной в сакральной ее части, так и какойто части норм социализации в раннесарматском обществе. 


\section{Основная часть}

Цель данного исследования состоит в изучении раннесарматской детской субкультуры на археологическом источнике, который предполагает наличие репрезентативной выборки по детским захоронениям с детализацией возраста ${ }^{2}$. Объем накопленного материала позволяет всесторонне охарактеризовать детскую погребальную обрядность ранних кочевников II-I вв. до н.э. и рассмотреть распределение детской смертности по возрастным группам. Для выполнения этой задачи в работе были проанализированы материалы пяти могильников раннесарматского периода (Бережновка, Калиновка, Ковалевка, Первомайский, Перегрузное I), раскопанных на территории Волгоградской области. Каждый из представленных могильников содержал в себе достаточное количество детских захоронений, которые в сумме составили серию из 132 погребений.

При изучении данного материала мы использовали следующие методы. Половозрастная структура исследуемых палеопопуляций изучалась методом построения таблиц смертности, в которых содержатся палеодемографические показатели по следующим возрастным группам детей: 0-1 год; 1-4 года; 5-9 лет и 10-14 лет. Специфика погребального обряда возрастных когорт детей изучалась статистическими методами. Результаты первого и второго исследований обрабатывались с помощью компьютерной программы Exel 95 для составления следующих гистограмм: распределение смертности детей по возрастным группам; распределение признаков погребального обряда и вещевого материала по возрастным группам детей и др. Подобная обработка материала позволяет наиболее эффективно проводить анализ эволюции детского погребального обряда в рассматриваемый период.

\section{Возрастная структура детских погребений}

Материал по всем пяти исследуемым могильникам составил 272 костяка, на долю которых приходится 132 детских костяка $(51,5 \%$ : 48,5 \%). Больше половины детей всех возрастных групп были погребены в курганахкладбищах и найдены в индивидуальных могилах (64,1 \%) (табл. 1, рис. 1-3). Причем этот показатель по всем возрастным группам более $50,0 \%$ от общей детской численности. В парных и коллективных могилах оказалось около 36,0 \% детей (рис. 4). По отдельным могильникам распределение детей в индивидуальных и коллективных могилах аналогичное, что и в суммарной выборке. Так, в могильнике Бережновка в индивидуальных могилах было погребено 77,4 \% детей, а в парных и коллективных могилах - 22,6 \%; в могильнике Калиновка соответственно: 81,7 и $10,3 \%$; в могильнике Ковалевка: 66,7 и 33,3 \%; в могильнике Первомайский: 47,4 и 52,6 и в могильнике Перегрузное I: 48,3 и 51,7 \% (рис. 5).

В парных погребениях сочетания самые разные: мужчина и ребенок (могильник Калиновка: погр. 9 кург. 3; погр. 23 кург. 12; погр. 21 кург. 19; могильник Перегрузное I: и др.); кург. 13 и др.); женщина и ребенок (могильник Калиновка: погр. 26 кург. 12; погр. 16 кург. 19; могильник Бережновка II: погр. 6 кург. 62 и погр. 2 кург. 63, группа II; могильник Ковалевка: погр. 8 кург. 1; могильник Первомайский VII: погр. 7 кург. 36 и погр. 10 кург. 39 и др.); ребенок + ребенок (могильник Калиновка: погр. 4 кург. 19 и погр. 2 кург. 55; могильник Бережновка II: погр. 1 кург. 65, группа II; могильник Ковалевка: погр. 3 кург. 4; могильник Перегрузное I: погр. 13 кург. 13 и др.). В коллективных могилах встречаются останки от трех до шести индивидов, часть из которых дети (могильник Калиновка: погр. 11 кург. 19; могильник Бережновка II: погр. 6 кург. 3; погр. 21 и 28 кург. 14; могильник Ковалевка: погр. 12 кург. 1; могильник Перегрузное I: погр. 5 кург. 12; могильник Первомайский VII: погр. 13 кург. 39 и др.) (рис. 4).

Прежде чем приступить к характеристике детских групп, следует отметить, что половозрастные определения по группам Бережновки были взяты из работы Б.В. Фирштейн [Фирштейн, 1970, табл. 1, с. 76-84] и из публикаций И.В. Синицына [Синицын, 1959; 1960]. Возможно, определения возраста детей, приведенные в публикациях И.В. Синицына, не совсем корректные, так как там отсутствуют дети младенческого возраста. Нет у него 
и детализации возраста по шести детям: из погребения 4 кургана 5 южной группы Бережновки; из погребения 24 и 28 (костяк 3) кургана 14, из погребения 8 и 11 кургана 65 группы II и погребения 23 кургана 35 группы I. Bо всех случаях кости детей сохранились, и поэтому, используя данные, приведенные в работах И.В. Синицына, и корректируя их с определениями Б.В. Фирштейн [Фирштейн, 1970, табл. 1, с. 76-84], можно получить представление о возрастной структуре детского населения, оставившего курганные группы у с. Бережновка.

Половозрастные определения по могильнику Калиновка взяты из описания погребений В.П. Шиловым и статьи В.В. Гинзбурга [Шилов, 1959; Гинзбург, 1959]. По трем остальным могильникам: Ковалевка, Первомайский и Перегрузное I, антропологические определения возраста детей наши.

Следует отметить, что более полная информация по демографии всех серий имеется в опубликованных нами раннее работах [Балабанова, 2009; Балабанова и др., 2014]. Все опубликованные раннесарматские группы, включая и нижнедонские, характеризуются высокими показателями детской смертности, что является не исключением, а правилом [Балабанова, 2009, с. 8; Батиева, 2011].

Итак, суммарная серия по исследуемым могильникам характеризуется высокой долей детей (48,5 \%), которую нужно воспринимать как результат высокой детской смертности с высоким инфекционным фоном, которым характеризуются, в том числе и древние кочевые общества с ранними формами производящего хозяйства (табл. 1). Кроме этого, в отличие от последующих эпох, среднесарматской и позднесарматской, погребальная практика курганов-кладбищ позволяла в раннесарматское время хоронить всех детей под курганами [Балабанова и др., 2015, с. 133].

Проанализируем возрастные когорты детей: от новорожденности до 1 года; от 1 года до 4 лет; от 5 лет до 9 лет и от 10 лет до 14 лет.

В серии без учета материалов могильника Бережновка доля младенцев в группе 04 лет составляет $37,8 \%$, а в доле общей численности детей (0-14 лет) - 21,2 \% (табл. 1). Похожее распределение младенцев в детской серии и в отдельно взятых могильниках. Так, доля младенцев в могильнике Калиновка составила $21,1 \%$ от общей численности детей и $35,3 \%$ от количества детей в возрасте 04 лет. В могильнике Ковалевка этот показатель самый высокий, и составил 40,0 \% от общей численности детей и 75,0 \% в группе от новорожденности до 4 лет. Это связано со спецификой погребальной обрядности кург. 1, в котором было погребено 10 детей. На момент смерти шестеро их них находились в возрасте до 1 года [Мыськов и др., 2006]. По могильнику Первомайский младенческая смертность находится в пределах 50,0 \% от общей смертности детей в возрасте 0-4 года и на уровне $20,0 \%$ от общей численности всех детей. Что касается этого же показателя по могильнику Перегрузное I, то он составил $47,6 \%$ от численности детей в группе 0 -4 года и $34,5 \%$ от общей численности всех детей (0-14 лет). Все вышеприведенные значения условной младенческой смертности соотносятся с результатами исследований по древним и традиционным культурам, так как было подсчитано, что от 10 до 40,0 \% новорожденных детей не доживают до конца первого года жизни по ряду причин, включая и практикуемый повсеместно инфантицид [Weiss, 1973, p. 49]. Как известно, младенческая смертность является одним из важных показателей благополучия общества. Его удельный вес тесно связан с материальными условиями существования населения и отношением в обществе к здоровью матери и только что родившегося ребенка. Показатель, который был вычислен для исследуемой группы, характеризующий древние общества, находится на нижнем уровне.

Следующий показатель - это доля детей от 1 года до 4 лет. В суммарной серии он составляет 34,8 \% от количества детей в возрасте 0-14 лет и 16,9\% от общего количества серии. По отдельным могильникам он сопоставим с вышеприведенными значениями, за малым исключением. Так, в могильнике Бережновка, учитывая то, что в этой группе не выделялись дети младенческого возраста, доля детей 0-4 лет составляет 61,3 \% от общей детской численности и 28,8 \% от численности всей выборки в целом. В могильнике Калиновка дети от 1 до 4 лет составили 26,3\% от общей численности детей и 13,7 \% от об- 
щей численности выборки; в могильнике Ковалевка соответственно: 13,3 и 9,1 \%; в могильнике Первомайский: 21,05 и 7,5\%; в могильнике Перегрузное I: 37,9 \% от численности детской группы (0-14 лет) и 19,0\% от общей численности серии.

Таким образом, почти для всех могильников характерно то, что доля данной возрастной группы с группой детей младенческого возраста составляет около половины детской серии и около одной трети от общей численности исследуемой популяции (табл. 1, рис. 2). Доля детей от новорожденности до 4 лет по отдельным могильникам сопоставима с долей по суммарной серии. В трех случаях она больше 50,0 \% (могильник Бережновка 61,3 \%; могильник Ковалевка - 53,3 \%; могильник Перегрузное - 72,4 \%), а в двух больше 40,0 \% (могильник Калиновка $47,4 \%$; могильник Первомайский - 42,1 \%).

Возрастная группа 5-9 лет составляет $12,5 \%$ от общей численности выборки и около $1 / 4(25,8 \%)$ от общей численности детей. По отдельно взятым могильникам доля детей этой возрастной группы распределяется следующим образом: в могильнике Бережновка: 12,1 и $25,8 \%$; в могильнике Калиновка: 18,1 и $34,2 \%$; в могильнике Ковалевка: 22,7 и $33,4 \%$; в могильнике Первомайский: 9,4 и $26,3 \%$ и в могильнике Перегрузное I: 5,2 и $10,3 \%$.

Что касается подростковой группы (1014 лет), то она составляет всего $8,8 \%$ от общей численности выборки и чуть меньше $1 / 5$ $(18,0 \%)$ от общей численности детской выборки. В отдельных могильниках, как и доля детей от 5 до 9 лет, имеет свою специфику. Близкие к показателям суммарной выборки имеют серии из могильников Калиновка $(9,7$ и $18,4 \%$ и Перегрузное I (8,6 и 17,3\%). Чуть ниже показателей суммарной выборки у серий могильников Бережновка (6,1 и 12,9 \%) и Ковалевка $(9,1$ и 13,3 \%). Аналогичные показатели могильника Первомайский $(11,3$ и 31,6 \%) гораздо выше как показателей суммарной выборки, так и показателей отдельно взятых могильников.

Таким образом, демографические показатели свидетельствуют о том, что до 45 лет не доживало более половины детей, до возраста 5-10 лет - 1/4 часть детей и до 14-
15 лет около 1/5 их части (рис. 2). Сравнительный анализ показал, что распределение смертности по детям раннесарматских популяций сопоставимо с аналогичными показателями народов с традиционными формами хозяйствования аграрного типа. Что касается высокой смертности в возрасте 04 лет, то ее можно объяснить как смертностью от различных инфекционных заболеваний, так и стрессами, испытываемыми детским организмом при переходе от молочного вскармливания к взрослой пище [Балабанова и др., 2015, с. 182; Бужилова, 1998, с. 144; Добровольская, 2005, с. 296]. Нельзя исключить и случаи инфантицида, который был легальной формой регулирования численности детей даже в античных цивилизациях вплоть до IV в. н.э., уже не говоря об обществах варваров раннего железного века [Ллойд де Моз, 2000, c. 84].

Ожидаемая продолжительность жизни $\left(\mathrm{E}_{0-4}\right)$ - величина, выражающая среднюю длину жизни целого поколения и являющаяся функцией, определяющей интенсивность смертности при рождении, составляет по суммарной серии около 21 года и сопоставима с аналогичными показателями по всем исследуемым могильникам, кроме серии из могильника Ковалевка (13,3 лет), в котором он гораздо ниже из-за большой доли детей от новорожденности до 4 лет (75,0 \%) (табл. 1). Значения ожидаемой продолжительности жизни как по суммарной серии, так и по сериям из отдельно взятых могильников соответствуют величинам, характеризующим общества эпохи бронзы и раннего железного века с ранними формами производящего хозяйства [Weiss, 1973].

Результаты демографического исследования как суммарной серии, так и серий исследуемых могильников в отдельности, позволяют констатировать наличие стандартной картины распределения детской смертности по возрастным группам исследуемой общности (табл. 1, рис. 3). Во всех могильниках пик смертности приходится на первую возрастную когорту 0-4 года, затем происходит постепенное снижение смертности от группы детей 59 лет к группе подростков 10-14 лет. Незначительные различия, которые наблюдаются по отдельным могильникам, связаны как со 
спецификой их погребальной обрядности, так и с другими причинами. К ним можно отнести неполноту половозрастных определений раскопанных погребений; отсутствие костей в ограбленных погребениях; неполные раскопки могильника и др. Стандартность распределения смертности детей в могильниках раннесарматского времени особенно отчетливо видна при сравнении аналогичных показателей с сериями из могильников среднесарматского и позднесарматского времени [Балабанова, 2009, с. 9; Балабанова и др., 2015, c. 132-135].

\section{Дифференциация погребального обряда детей}

Погребальный обряд можно представить как комплексное явление, включающее в себя социальные, духовные и физические взаимосвязи. При этом анализ физических составляющих, прежде всего антропологических останков, может предоставить в распоряжение исследователя критерии для более строгого выделения в обряде блоков социальной и культурной информации.

Анализ детских погребальных сооружений (табл. 2, рис. 5) показывает, что в раннесарматский период детей в младенческом возрасте хоронили на древней поверхности $(36,0 \%)$, в гробу $(16,0 \%)$, в могильной яме $(64,0 \%)$. Из них в ямах подбойной конструкции $-40,0 \%$, прямоугольной формы, в том числе и в яме с заплечиками $-20,0 \%$, в катакомбе $-14,2 \%$. Все случаи погребения детей младенческого возраста как в могиле катакомбной конструкции, так и в гробу были в парных или коллективных захоронениях вместе с умершими взрослыми сородичами. Так, например, в погребении 21 кургана 19 могильника Калиновка младенец сопровождал мужчину, а катакомба погребения 5 кургана 12 могильника Перегрузное I было склепом, содержащим пять скелетов, трое из которых были дети младенческого возраста [Шилов, 1959, c. 377 ; Балабанова и др., 2014, с. 21]. А младенец из погребения 8 кургана 1 могильника Ковалевка был похоронен вместе с женщиной в дощатом рамчатом гробу [Мыськов, Лапшин, Кияшко, 2006, с. 27]. В подбойных могилах зачастую сооружалась специальная ниша для ребенка, как это имело место в погребении 2 кургана 31 могильника Перегрузное I. Там, в длинной западной стенке могилы, на уровне дна была выкопана камера подбоя размерами: $0,82 \times 0,1 \times 0,43$ м, на дне которого лежал скелет младенца в возрасте 6 месяцев [Балабанова и др., 2014, с. 46].

При анализе погребальной обрядности детей в возрасте 1-4 лет выяснилось, что хоронили их на древней поверхности до $30,6 \%$, в гробу - до $4,1 \%$, в подбое - $18,4 \%$, в могилах прямоугольной и подквадратной конструкции, в том числе и в ямах с заплечиками - до $16,3 \%$ (табл. 2 , рис. 5). Как и при погребении младенцев в гробу, незначительная часть детей от 1 года до 4 лет также занимала свое место в совместном гробу вместе с погребенной женщиной или мужчиной.

Исследование погребений детей в возрасте 5-9 лет показало, что хоронили их на древней поверхности несколько реже, чем детей от 1 до 4 лет $(23,5 \%)$, а в гробу чаще $(17,6 \%)$. Более $1 / 3$ было погребено в подбое $(32,4 \%)$ и в могилах прямоугольной и подквадратной формы, в том числе и в ямах с заплечиками $(38,2$ \%). И лишь один ребенок был обнаружен в могиле катакомбной конструкции, которая содержала 5 костяков, в том числе и ребенка 6-7 лет [Балабанова и др., 2014, с. 2].

Что касается подростков в возрасте 10 14 лет, то их еще реже $(12,5 \%)$ хоронили в насыпи, чем младшие возрастные группы. Для них характерны как индивидуальные могилы $(54,2 \%)$, так и парные и коллективные $(45,8 \%)$. Пятеро из них находились в составе крупных коллективных усыпальниц, от трех до 6 человек; четверо - в парных: с индивидами того же возраста, с младшими детьми или с умершими взрослыми членами сообщества. Что касается типов могильных ям, то известно лишь два захоронения подростков в коллективной катакомбе $(8,3 \%)$. В погребении 12 кургана 1 могильника Ковалевка кроме подростка были обнаружены останки женщины около 40 лет и ребенка около 3 лет, а в катакомбном захоронении 10 кургана 39 могильника Первомайский VII вместе с подростком обнаружен скелет женщины 40-45 лет [Мыськов, Лапшин, Кияшко, 2006, с. 36; Мамонтов, 2000 , c. 42-43]. 
Подбойные захоронения в этой группе составляют 33,4 \%. Остальные умершие были погребены в простых ямах прямоугольной и подквадратной формы - 45,8 \%. Таким образом, для 41,7 \% лиц этого возраста устраивались могильные ямы усложненной конструкции. В гробу хоронили до 12,5 \% подростков.

Что касается ориентировки головы погребенных детей, то во всех группах преобладает южная. Ориентировка в северный сектор по разным детским группам находится в пределах 9-12\%, в остальных случаях либо ориентировка не определена, либо в западный или восточный сектор.

Таким образом, из вышеприведенного анализа вытекает то, что где-то около половины детей разных возрастных групп погребалось в раннесарматское время в могильных ямах сложной конструкции: подбоях и катакомбах. Остальная часть умерших детей была погребена в простых ямах, прямоугольной или подквадратной формы, иногда усложненных специально сооруженными заплечиками.

\section{Вещевой комплекс}

Наиболее существенным признаком, отличающим детские погребения раннесарматской культуры, является качественно-количественный состав сопроводительного инвентаря, который отличается в погребениях разных возрастных групп. Пятая часть детских могил $(21,5 \%)$ достоверно не содержала сохранившегося погребального инвентаря (табл. 3, рис. 6). Безынвентарные захоронения по возрастным группам распределяются следующим образом:

1) дети младенческого возраста составили более половины (52,0 \%);

2) дети группы 1-4 года составили 4,1 \%;

3) дети возрастной группы 5-9 лет составили $26,5 \%$; $16,7 \%$.

4) подростки 10-14 лет составили

Большая часть детей всех возрастных групп, при которых отсутствовал инвентарь, была получена при раскопках коллективных и парных могил. Таким образом, основная характеристика захоронений детей младенческого возраста - редкость или отсутствие боль- шинства категорий предметного комплекса, распространенных в могилах взрослого населения и детей более старшего возраста. Чаще всего в погребениях младенцев находят лепные сосуды (18,5\%). Изредка встречаются другие керамические сосуды: кувшин $(3,7$ \%); курильница (3,7 \%); фрагмент алебастрового сосуда $(3,7 \%)$ и миска $(3,7 \%)$. Кроме посуды при младенцах обнаружили по одному разу нож и ритуальное вещество и два раза бусы и кости мелкого рогатого скота.

Наиболее распространенной категорией вещей в погребениях детей от одного года до четырех лет была керамическая посуда лепной формы (около $61 \%$ от всех могильных ям). Кроме лепных сосудов, коллекция содержит шесть курильниц $(13,0 \%)$ и три кувшина $(6,5 \%)$. В погребениях этой группы детей была встречена сопроводительная пища, представленная частями туш мелкого рогатого скота (13 случаев, что составляет $28,3 \%$ ). Не считая посуды, наиболее частой находкой в детских погребениях являются украшения, преимущественно это бусины, которые выявлены в 11 погребениях. В трех случаях найдено ритуальное вещество; в двух нож; в одном - бронзовый перстень. Бронзовое зеркало также было обнаружено в одном погребении. Предметы вооружения редко встречаются в детских погребениях возрастной группы 1-4 года и представлено единичной находкой бронзового наконечника стрелы $(2,2 \%)$. Еще несколько предметов было встречено по одному разу, это: клык кабана; костяная трубочка; каменная плитка; пряслице; антропоморфная фигурка из мела и раковина.

В погребениях детей возрастной группы от 5 до 9 лет также наиболее распространенной категорией вещей являются лепные сосуды (54,3\% от всех могил этой группы). Кроме этого, из других типов посуды в трех погребениях были встречены кувшины (3 кувшина, что составляет 8,6 \% от количества погребений этой возрастной группы). Три раза встречены другие типы посуды: в погребении 9 кургана 65 могильника Бережновка II в головах погребенного рядом с костями овцы в процессе раскопок был обнаружен алебастровый сосудик [Синицын, 1960, с. 72]; в погребении 7 кургана 1 мо- 
гильника Ковалевка миска гончарная сероглиняная стояла на дне в С3 углу подбоя; в погребении 5 кургана 5 южной группы могильника Бережновка в ногах ребенка 67 лет рядом с гончарным серолощеным кувшином находился миниатюрный мраморный сосудик [Мыськов, Лапшин, Кияшко, 2006; Синицын, 1960, с. 113, 114].

В захоронениях этой группы детей с наибольшей частотой встречаются остатки жертвенных животных, передняя нога овцы с лопаткой (42,9 \%) и один раз обнаружены кости от крупного рогатого скота, ребра и кости конечностей (погр. 1 кург. 16, могильник Бережновка II).

Оружие в погребениях детей от 5 до 9 лет представлено кинжалом из погребения 7 кургана 1 могильника Ковалевка [Мыськов, Лапшин, Кияшко, 2006, с. 26], мечом из погребения 11 кургана 19 могильника Калиновка [Шилов, 1959, с. 374], копьем из погребения 1 кургана 16 могильника Бережновка II [Синицын, 1960, с. 32] и стрелами из погребения 1 кургана 5 могильника Первомайский I [Демиденко, Демиденко, Мамонтов, 2006, с. 191].

Из бытовых предметов в погребениях детей 5-9 лет были обнаружены железные ножи $(11,4 \%)$ и пряслица (14,2\%). Все ножи однолезвийные, небольших размеров. Всего их насчитывается четыре экземпляра. Более представительной является такая категория, как бусы. Они составляют 25,7 \% от общего количества погребений данной группы детей и встречаются в девяти погребениях. Пряслица найдены в пяти погребениях. Остальные артефакты погребений данной возрастной когорты представлены единичными экземплярами: костяные ложечки (два случая); зеркало (два случая); перстень (один случай); фигурка из мела (один случай); подвески (три случая); оселок (один случай); пряжка (один случай) и т. д.

Выборка погребений подростков (1014 лет) составляет 24 могильные ямы. Среди этой возрастной группы зафиксированы 16,7 \% (четыре) безынвентарных погребения. Восемь погребений содержали только кости животных, переднюю ногу и лопатку барана (33,3\%). Лепная керамическая посуда была обнаружена в десяти ямах, везде по одному сосуду (41,6 \%). Из других типов посуды в могилах подростков встречались кувшины 6 (25,0 \%), в том числе и изготовленные на гончарном круге, трехручный канфар из погребения 4 кургана 12 могильника Перегрузное I [Балабанова и др., 2014, с. 21], алебастровый сосуд из погребения 4 кургана 4 могильника Ковалевка [Мыськов, Лапшин, Кияшко, 2006, с. 56] и др. Следует отметить, что вещевой инвентарь более разнообразен, чем в погребениях младших возрастных групп. Наиболее распространенными бытовыми предметами являются пряслица, которые были встречены в 7 погребениях (29,2 \%), и ножи (12,5\%). Бусы также остаются наиболее распространенными украшениями - найдены в четырех погребениях (16,7 \%). В одном из них (Калиновка, кург. 19, погр. 3 ) была обнаружена веточка коралла, в наборе имелись разнотипные бусы: гешировые дисковидные; стеклянная пронизь; мелкие бусины из светлого стекла (бисер). Кроме этого, в черепе подростка из погребения 3 кургана 19 могильника Калиновка были обнаружены два спиральных колечка из серебряной проволоки; у погребенного из погребения 7 кургана 12 могильника Калиновка бронзовое височное кольцо.

Предметы вооружения зафиксированы лишь в пяти погребениях. В двух погребениях кургана 39 могильника Первомайский VII они представлены одним наконечником стрелы: в погребении 10 - бронзовый втульчатый; в погребении 13 - трехлопастной железный [Mамонтов, 2000, с. 43]. В трех других могильных ямах была расчищена пачка стрел, видимо, из колчанного набора (погр. 7 кург. 36, могильник Первомайский VII; погр. 10 кург. 8, могильник Калиновка и погр. 1 кург. 33, могильник Перегрузное I) [Мамонтов, 2000, с. 38; Шилов, 1959, с. 346]. Два раза были зафиксированы в погребении костяные ложечки, вырезанные из лопатки барана [Балабанова и др., 2014, c. 56].

\section{Обсуждение результатов и основные выводы}

Вышеприведенная картина распределения смертности по возрастным группам детей и подростков, а также специфика погребального обряда и размещения предметных комплексов в погребениях детей и подрост- 
ков позволяет сделать ряд обобщений, которые дают основание строить предположения.

1. Детская погребальная практика по исследованным раннесарматским могильникам позволяет говорить о том, что в ней наиболее полно символизирована вертикальная социальная структура, отражающаяся на статусном отношении возрастных групп. Несмотря на размытость границ, существование вертикальных обрядовых групп не вызывает сомнений. Погребения с более богатым вещевым комплексом принадлежали подросткам, a с незначительным количеством инвентаря или безынвентарные - младенцам.

2. В обществах ранних кочевников Нижнего Поволжья II-I вв. до н.э. дети и подростки погребались по одному и тому же обряду, что и взрослые, но их могилы содержали более скудный инвентарь.

3. Как и в погребениях взрослых, в погребениях детей разных возрастных групп кости животных, сосуды и украшения являются наиболее частыми находками.

4. Больше половины захоронений младенцев были безынвентарными, количество которых снижается по мере увеличения прожитых лет ребенком.

5. Для детей часто сооружались глубокие и сложные по устройству могилы, но периферийные по локализации, а иногда в коллективных склепах они помещались в специальные ниши.

6. В качестве заупокойной пищи всем детям клали всегда только переднюю конечность с лопаткой мелкого рогатого скота.

7. Значимость детей в раннесарматском обществе оценивалась по количеству прожитых лет.

8. Изученная серия детских захоронений под курганами-кладбищами позволяет предположить наличие в раннесарматском обществе социально значимых возрастных групп детей: от 0 до 4-5 лет, от 5 до 10 лет и 1014 лет. Первая характеризуется абсолютным преобладанием гендерно-нейтрального сопроводительного инвентаря. Вторая и третья группы отражают процесс гендерной и возрастной социализации.

Наш материал не противоречит ранее высказанному выводу о том, что «гендерная дифференциальная социализация начиналась, вероятно, в возрасте около 5 лет» [Берсенева, Гильмитдинова, 2013, с. 43]. Выборка нижневолжских детских погребений показывает, что именно в погребениях детей старше 5 лет появляются наборы вещей, которые можно связать с определенным гендером. Видимо, это связано с тем, что начиная с этого возраста дети вовлекались в различные виды деятельности: прядение, вязание; уход за скотиной и выпас ее и т. д. Вид деятельности, требующий применения оружия, слабо отражен на археологическом материале детских погребений. Наличие его в отдельных погребениях детей старше 5 лет позволяет констатировать умение им пользоваться и при необходимости использовать в бою. Скорее всего, у ранних сарматов, как и у осетин, дети возрастной группы от 3 до 7 лет считались уже полноправными членами семьи. Возрастной рубеж 7 лет играл важную роль. У осетин это возраст, когда мальчик играл луком и стрелой, его сажали на коня и давали поручения по хозяйству [Туаева, 2008].

Кроме вышесказанного, изучение детских раннесарматских погребальных комплексов позволяет выдвинуть предположение о том, что в ряде случаев захоронение детей не предполагало создания традиционного погребального сооружения. Это объясняет большой процент детских коллективных захоронений. Анализ раннесарматских комплексов продемонстрировал высокую степень вариабельности элементов детской обрядовой практики, имеющих как общие, так и отличительные черты по сравнению с захоронениями взрослых членов социума. Анализируемая серия детских захоронений показала наличие достаточно четкой дифференциации. Отдельные погребения демонстрируют показатели, отражающие попытку обозначения принадлежности умершего ребенка к гендерной группе взрослых.

Возможности антропологического определения возраста детей и подростков, а также анализ археологических материалов позволяют определить этапы социализации в раннесарматском обществе. Результаты исследования показали, что снабжение детей сопроводительными предметами было, видимо, менее обязательно, чем погребения взрослых и подростков, которые заметно выделяются 
M.A. Balabanova. Morphology of Child Burials of Early Nomads in the Lower Volga Region

более частым присутствием предметов сопроводительного инвентаря, не встреченных в захоронениях детей младших групп.

Таким образом, на каждом возрастном этапе складывалась своя субкультура, которая формировала условия социализации, осуществляемой через трудовое воспитание в семье при натуральном хозяйстве. Видимо, смена предметного мира, который окружал ребенка определенного возраста, был связан с обязанностями в доме. Первые обязанности ребенка в семье были, скорее всего, в виде простых поручений и просьб. Изменение предметного комплекса, а значит и режима жизни ребенка, свидетельствовало о переходе в новую возрастную категорию, а, следовательно, и к новому этапу социализации. Четкое возрастное и половозрастное распределение обязанностей, принципы поведения, специфические способы общения способствовали тому, что дети осваивали опыт предшествующих поколений на уровне наблюдения и по- вторения их поведения. Таким образом, дети уже к 7-8 годам становились ответственными за свое общественное поведение и трудовые обязанности.

В результате уже к 14-15 годам подростки могли брать на себя все основные хозяйственные задачи и социальные роли, как это было принято у осетин [Туаева, 2008]. С этого возраста мальчики активно включались в домашнее хозяйство, выполняли мужские дела, самостоятельно могли сидеть на лошади, их начинали обучать приемам борьбы, национальным танцам. В 16 лет юноши переходили во «взрослый» класс, с этого времени юноша мог носить оружие и вступать в брак. Что касается девочек, то они обособлялись от мальчиков в 6-8-летнем возрасте, а с 10 лет помогали матери в хозяйстве, обучались рукоделию и т. д. К 12-14 годам девочки объединялись в особый возрастной класс, с соблюдением строгих норм традиционного этикета. К 16-18 годам девушка обретала статус невесты. 
M.А. Балабанова. Морфология детских захоронений ранних кочевников Нижнего Поволжья

\section{ИЛЛЮСТРАЦИИ}

Таблицуа 1

\section{Демографические показатели по детским группам могильников раннесарматской культуры (II-I вв. до н.э.)}

\begin{tabular}{|c|c|c|c|c|c|c|c|}
\hline $\begin{array}{c}\text { \% / возрастные } \\
\text { группы }\end{array}$ & $0-1$ год & 1-4 года & 5-9 лет & 10-14 лет & $\mathrm{E}_{0-4}$ & $\begin{array}{l}\text { Доля детей в } \\
\text { могильнике / } \\
\text { детская } \\
\text { смертность } \\
\end{array}$ & $\begin{array}{l}\mathrm{AA} \\
\text { (лет) }\end{array}$ \\
\hline \multicolumn{8}{|c|}{ Могильник Бережновка } \\
\hline $\begin{array}{l}\text { Доля в суммарной } \\
\text { выборке }\end{array}$ & & $\begin{array}{c}19 \\
(28,8 \% *)\end{array}$ & $\begin{array}{c}8 \\
(12,1 \%)\end{array}$ & $\begin{array}{c}4 \\
(6,1 \%)\end{array}$ & \multirow[t]{2}{*}{21,5} & \multirow[t]{2}{*}{$39,7 \%$} & \multirow[t]{2}{*}{36} \\
\hline $\begin{array}{l}\text { Доля в детской } \\
\text { выборке }\end{array}$ & & $61,3 \%$ & $25,8 \%$ & $12,9 \%$ & & & \\
\hline \multicolumn{8}{|c|}{ Могильник Калиновка } \\
\hline $\begin{array}{l}\text { Доля в суммарной } \\
\text { выборке }\end{array}$ & $\begin{array}{c}8 \\
(11,0 \%) \\
\end{array}$ & $\begin{array}{c}10 \\
(13,7 \%) \\
\end{array}$ & $\begin{array}{c}13 \\
(18,1 \%) \\
\end{array}$ & $\begin{array}{c}7 \\
(9,7 \%) \\
\end{array}$ & \multirow[t]{2}{*}{20,3} & \multirow[t]{2}{*}{$38,5 \%$} & \multirow[t]{2}{*}{35,2} \\
\hline $\begin{array}{l}\text { Доля в детской } \\
\text { выборке }\end{array}$ & $\begin{array}{c}21,1 \% \\
(35,3 \% \text { доля младенцев } \\
\text { в группе } 0-4 \text { года }) \\
\end{array}$ & $26,3 \%$ & $34,2 \%$ & $18,4 \%$ & & & \\
\hline \multicolumn{8}{|c|}{ Могильник Ковалевка } \\
\hline $\begin{array}{l}\text { Доля в суммарной } \\
\text { выборке }\end{array}$ & $\begin{array}{c}6 \\
(27,3 \%) \\
\end{array}$ & $\begin{array}{c}2 \\
(9,1 \%) \\
\end{array}$ & $\begin{array}{c}5 \\
(22,7 \%) \\
\end{array}$ & $\begin{array}{c}2 \\
(9,1 \%) \\
\end{array}$ & \multirow[t]{2}{*}{13,3} & \multirow[t]{2}{*}{$68,2 \%$} & \multirow[t]{2}{*}{30} \\
\hline $\begin{array}{l}\text { Доля в детской } \\
\text { выборке }\end{array}$ & $\begin{array}{c}40,0 \% \\
(75,0 \% \text { доля младенцев } \\
\text { в группе } 0-4 \text { года) } \\
\end{array}$ & $13,3 \%$ & $33,4 \%$ & $13,3 \%$ & & & \\
\hline \multicolumn{8}{|c|}{ Могильник Перегрузное I } \\
\hline $\begin{array}{l}\text { Доля в суммарной } \\
\text { выборке }\end{array}$ & $\begin{array}{c}10 \\
(17,2 \%)\end{array}$ & $\begin{array}{c}11 \\
(19,0 \%)\end{array}$ & $\begin{array}{c}3 \\
(5,2 \%) \\
\end{array}$ & $\begin{array}{c}5 \\
(8,6 \%)\end{array}$ & \multirow[t]{2}{*}{19,8} & \multirow[t]{2}{*}{$50,0 \%$} & \multirow[t]{2}{*}{34,9} \\
\hline $\begin{array}{l}\text { Доля в детской } \\
\text { выборке }\end{array}$ & $\begin{array}{c}34,5 \% \\
(47,6 \% \text { доля младенцев } \\
\text { в группе } 0-4 \text { года) } \\
\end{array}$ & $37,9 \%$ & $10,3 \%$ & $17,3 \%$ & & & \\
\hline \multicolumn{8}{|c|}{ Могильник Первомайский } \\
\hline $\begin{array}{l}\text { Доля в суммарной } \\
\text { выборке }\end{array}$ & $\begin{array}{c}4 \\
(7,5 \%) \\
\end{array}$ & $\begin{array}{c}4 \\
(7,5 \%) \\
\end{array}$ & $\begin{array}{c}5 \\
(9,4 \%) \\
\end{array}$ & $\begin{array}{c}6 \\
(11,3 \%) \\
\end{array}$ & \multirow[t]{2}{*}{24,5} & \multirow[t]{2}{*}{$35,2 \%$} & \multirow[t]{2}{*}{37,2} \\
\hline $\begin{array}{l}\text { Доля в детской } \\
\text { выборке }\end{array}$ & $\begin{array}{c}21,05 \% \\
(50,0 \% \text { доля младенцев } \\
\text { в группе } 0-4 \text { года }) \\
\end{array}$ & $21,05 \%$ & $26,3 \%$ & $31,6 \%$ & & & \\
\hline \multicolumn{8}{|c|}{ Суммарная серия } \\
\hline $\begin{array}{l}\text { Доля в суммарной } \\
\text { выборке }\end{array}$ & $\begin{array}{c}28 \\
(10,3 \%) \\
\end{array}$ & $\begin{array}{c}46 \\
(16,9 \%) \\
\end{array}$ & $\begin{array}{c}34 \\
(12,5 \%)\end{array}$ & $\begin{array}{c}24 \\
(8,8 \%) \\
\end{array}$ & \multirow[t]{2}{*}{21,0} & \multirow[t]{2}{*}{$48,5 \%$} & \multirow[t]{2}{*}{35,6} \\
\hline $\begin{array}{l}\text { Доля в детской } \\
\text { выборке }\end{array}$ & $\begin{array}{c}21,2 \% \\
(37,8 \% \text { доля младенцев } \\
\text { в группе } 0-4 \text { года }) \\
\end{array}$ & $34,8 \%$ & $25,8 \%$ & $18,2 \%$ & & & \\
\hline
\end{tabular}
0-4 года.

Примечание. * В этой колонке для могильника Бережновка приводятся данные по возрастной группе 


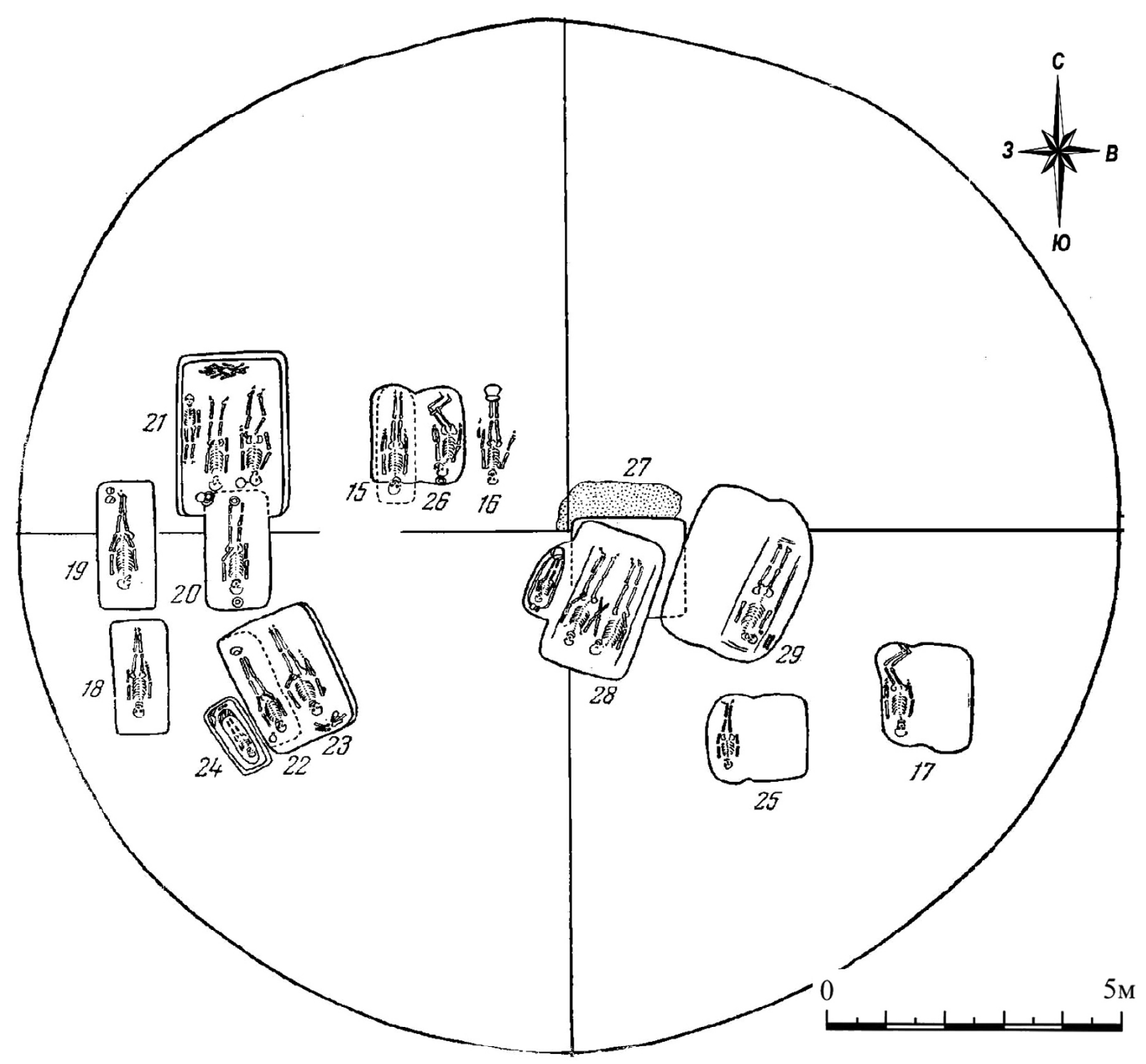

Рис. 1. Курган-кладбище № 14 II Бережновского могильника [Синицын, 1959]

Fig. 1. Barrow-cemetry no. 14 of II Berezhnovsky burial mound [Sinitsyn, 1959] 
М.А. Балабанова. Морфология детских захоронений ранних кочевников Нижнего Поволжья

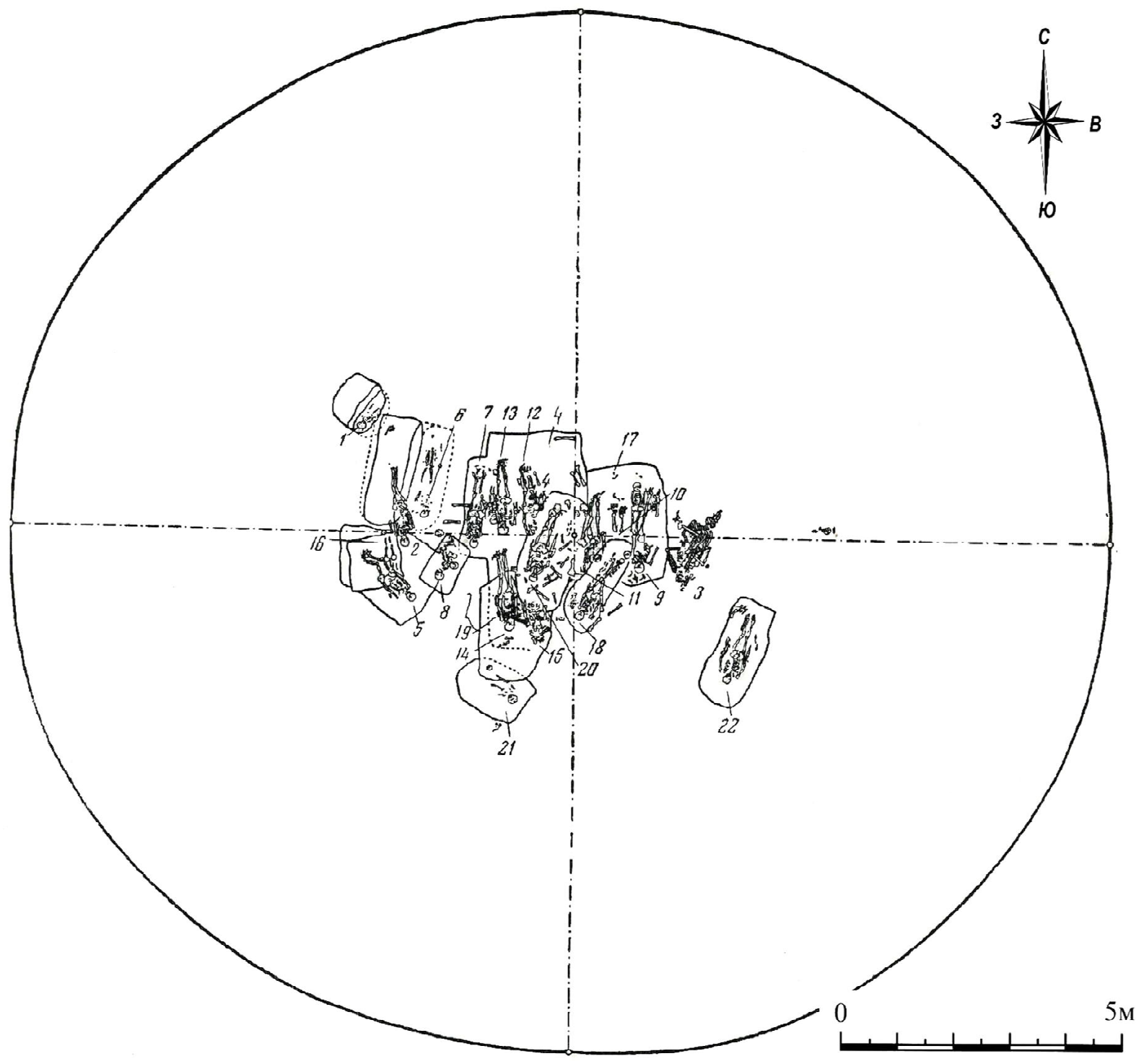

Рис. 2. Курган-кладбище № 3 Калиновского могильника [Шилов, 1959]

Fig 2. Barrow-cemetry no. 3 of Kalinovsky burial mound [Shilov, 1959] 


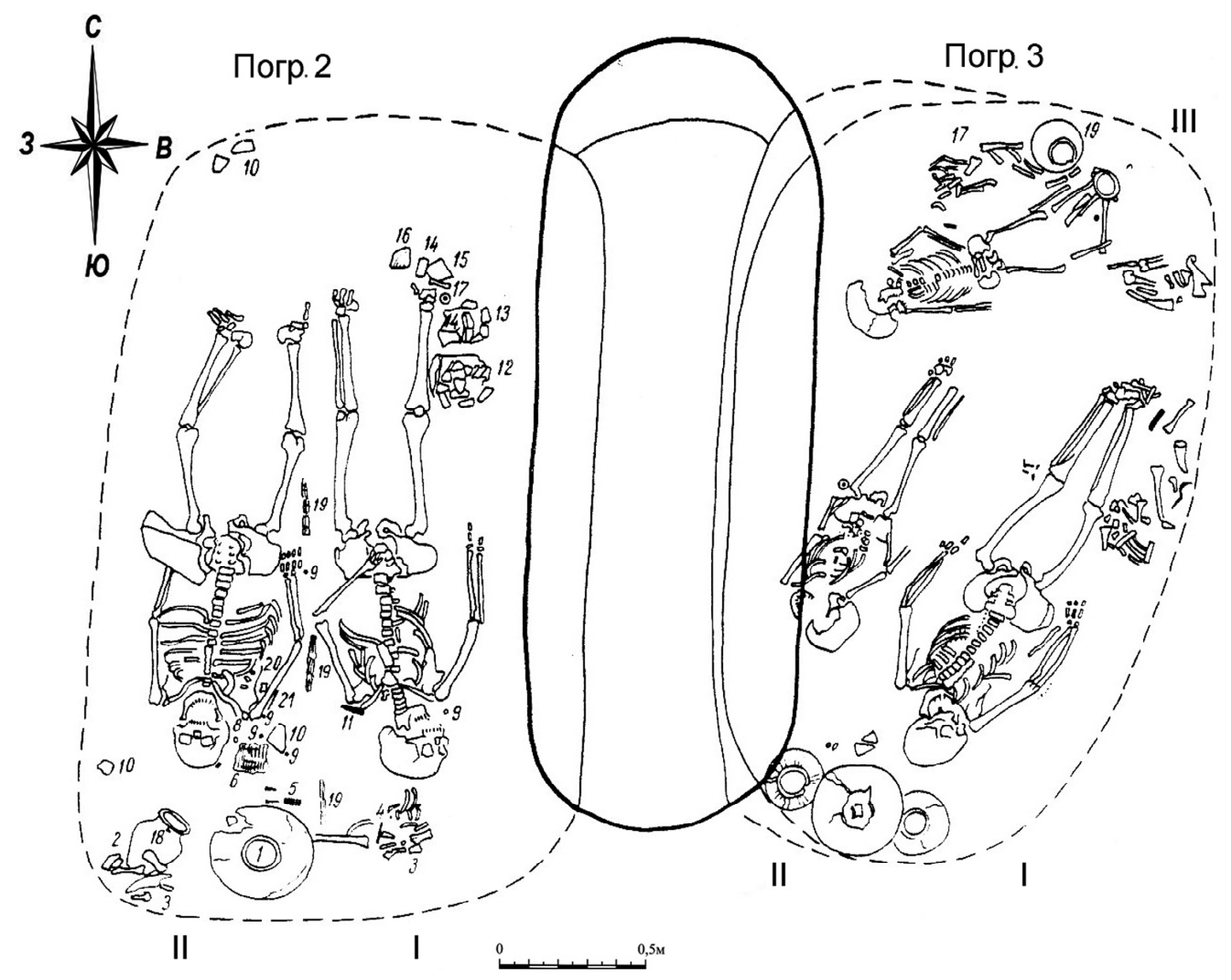

Рис. 3. Коллективные захоронения раннесарматского времени из могильника Старица, кург. 42, погр. 2 : костяк 1 - женщина 35-45 лет; костяк 2 - женщина 25-35 лет; погр. 3: костяк 1 - женщина старше 50 лет; костяк 2 - ребенок 5-7 лет; костяк 3 - ребенок около 7 лет

Fig. 3. Collective graves of the Early Sarmatian time from Staritsa burial mound, barrow 42, burial 2: skeleton 1 - a 35-45-year-old woman; skeleton 2 - a 25-35-year-old woman; burial 3: skeleton 1 - a woman over 50; skeleton 2 - 5-7-year-old child; skeleton 3 - a child about 7 years old 
М.А. Балабанова. Морфология детских захоронений ранних кочевников Нижнего Поволжья

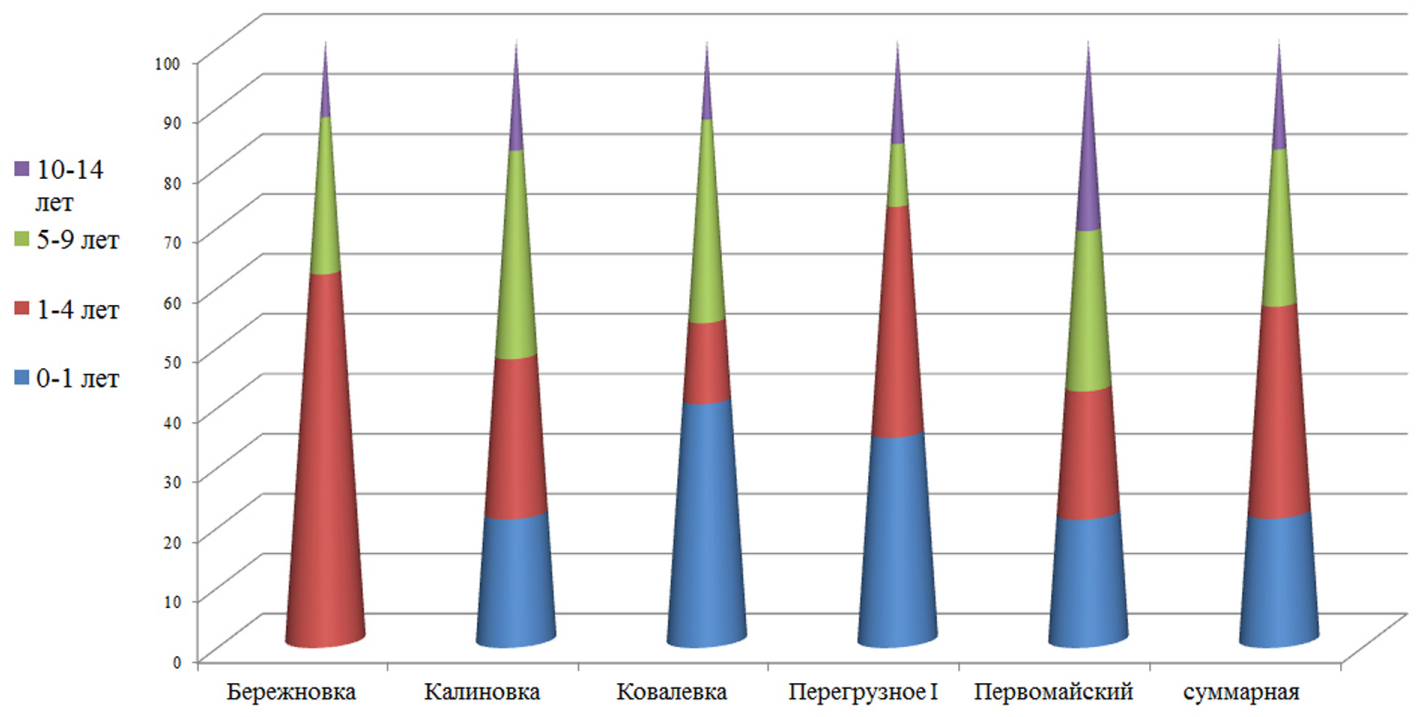

Рис. 4. Распределение смертности в детских раннесарматских когортах

Fig. 4. Mortality rates in children's early Sarmatian cohorts

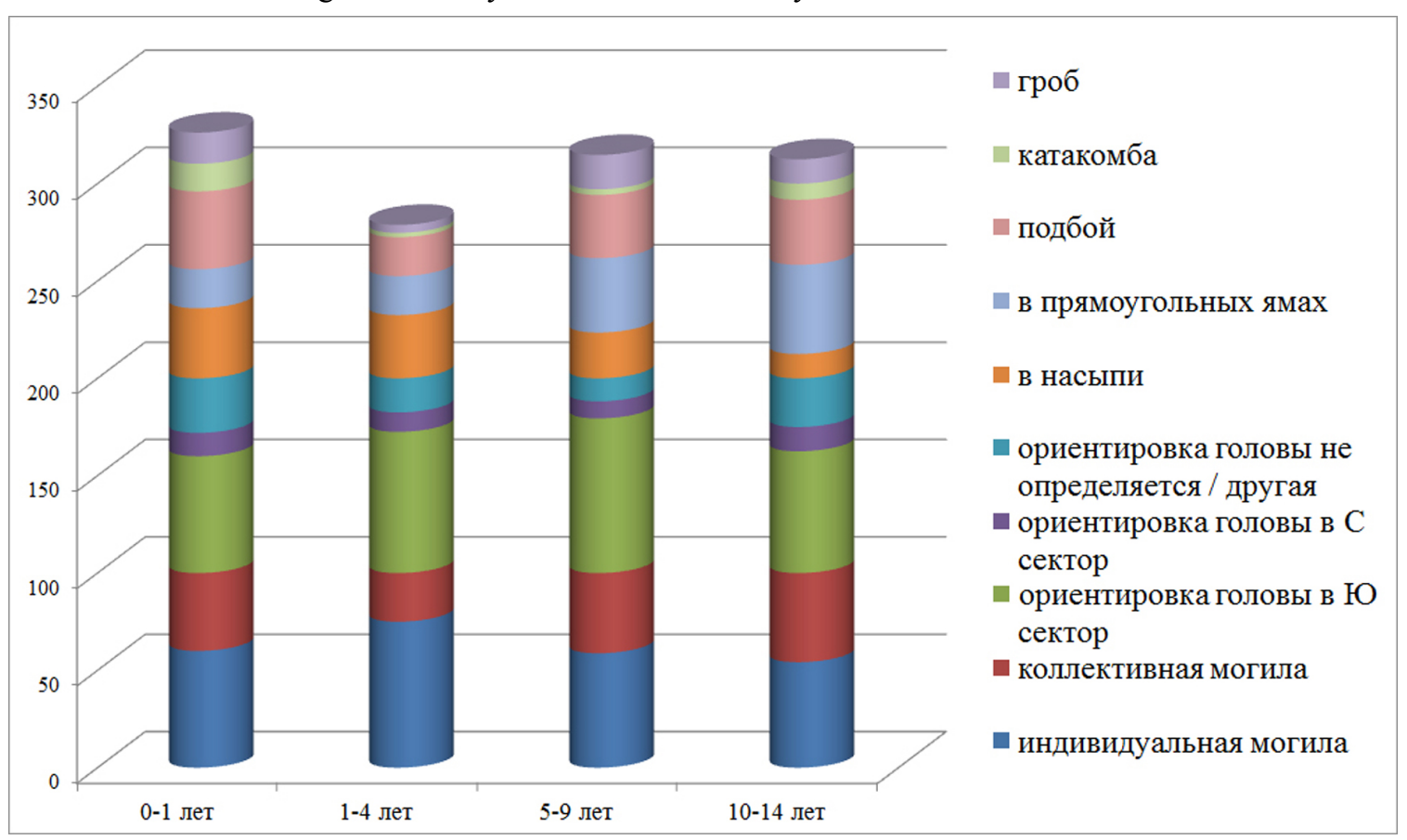

Рис. 5. Распределение признаков погребального обряда в погребениях индивидов от новорожденности до 14 лет

Fig. 5. Distribution of signs of burial rite in burials of individuals from newborns to 14-year-old adolescents

Таблииа 2

Распределение признаков погребальной обрядности в детских захоронениях, \%

\begin{tabular}{|l|r|r|r|r|r|r|r|r|r|r|}
\hline Возраст & $\begin{array}{c}\text { Индиви- } \\
\text { дуальная } \\
\text { могила }\end{array}$ & $\begin{array}{c}\text { Коллек- } \\
\text { тивная }\end{array}$ & $\begin{array}{c}\text { Ориенти- } \\
\text { ровка } \\
\text { головы } \\
\text { в Ю сектор }\end{array}$ & $\begin{array}{c}\text { Ориенти- } \\
\text { ровка } \\
\text { головы } \\
\text { в С сектор }\end{array}$ & $\begin{array}{c}\text { Ориенти- } \\
\text { ровка } \\
\text { головы не оп- } \\
\text { ределяется/ } \\
\text { другая }\end{array}$ & $\begin{array}{c}\text { В на- } \\
\text { сыпи }\end{array}$ & $\begin{array}{c}\text { Прямоу- } \\
\text { гольная/ } \\
\text { подквадрат- } \\
\text { ная яма }\end{array}$ & $\begin{array}{c}\text { Под- } \\
\text { бой }\end{array}$ & $\begin{array}{c}\text { Ката- } \\
\text { комба }\end{array}$ & $\begin{array}{c}\text { В } \\
\text { гробу }\end{array}$ \\
\hline $0-1$ лет & 60 & 40 & 60 & 12 & 28 & 36 & 20 & 40 & 14,2 & 16 \\
\hline $1-4$ лет & 75 & 25 & 72,5 & 10 & 17,5 & 30,6 & 16,3 & 18,4 & 2,2 & 4,1 \\
\hline $5-9$ лет & 58,8 & 41,2 & 79,4 & 8,8 & 11,8 & 23,5 & 38,2 & 32,4 & 2,9 & 17,6 \\
\hline $10-14$ лет & 54,2 & 45,8 & 62,5 & 12,5 & 25 & 12,5 & 45,8 & 33,4 & 8,3 & 12,5 \\
\hline
\end{tabular}




\section{Соотношение возраста погребенных и сопутствующего инвентаря}

\begin{tabular}{|c|c|c|c|c|c|c|}
\hline \multirow{2}{*}{$\begin{array}{c}\text { Воз- } \\
\text { раст- } \\
\text { ная ко- } \\
\text { горта }\end{array}$} & \multirow{2}{*}{$\begin{array}{l}\text { Количество } \\
\text { погребений }\end{array}$} & \multicolumn{4}{|c|}{ Керамика } & \multirow{2}{*}{$\begin{array}{c}\text { Инвентарь } \\
\text { (число погребений с данным инвентарем) }\end{array}$} \\
\hline & & $\begin{array}{c}\text { Лепной } \\
\text { сосуд }\end{array}$ & Кувшин & $\begin{array}{l}\text { Миска / кан- } \\
\text { фар / Ойнохоя } \\
\text { / алебастро- } \\
\text { вый сосуд / } \\
\text { мраморный } \\
\text { сосуд } \\
\end{array}$ & $\begin{array}{l}\text { Куриль- } \\
\text { ница }\end{array}$ & \\
\hline \multicolumn{7}{|c|}{ Суммарная серия } \\
\hline $0-1$ & $\begin{array}{c}28 \\
(21,2 \%) *\end{array}$ & $\begin{array}{c}5 \\
(17,9 \%) \\
\end{array}$ & $\begin{array}{c}1 \\
(3,6 \%)\end{array}$ & $\begin{array}{c}2 \\
(7,2 \%) \\
(7,2 \%\end{array}$ & $\begin{array}{c}1 \\
(3,6 \%)\end{array}$ & $\begin{array}{l}\text { Кости МРС (2); бусы (2); ритуальное веще- } \\
\text { ство (1); нож (1) }\end{array}$ \\
\hline $1-4$ & $\begin{array}{c}46 \\
(34,8 \%)\end{array}$ & $\begin{array}{c}28 \\
(60,9 \%)\end{array}$ & $\begin{array}{c}3 \\
(6,5 \%)\end{array}$ & & $\begin{array}{c}6 \\
(13,0 \%)\end{array}$ & $\begin{array}{l}\text { Кости МРС (13); бусы (11); ритуальное ве- } \\
\text { щество (3); нож (2); оселок (1); перстень (1); } \\
\text { зеркало (1); клык кабана (1); костяная трубка } \\
\text { (1); каменная плитка (1); пряслице (1); кин- } \\
\text { жал (1); антропоморфная фигурка из мела } \\
\text { (1); раковина (1) }\end{array}$ \\
\hline $5-9$ & $\begin{array}{c}34 \\
(25,8 \%)\end{array}$ & $\begin{array}{c}19 \\
(55,9 \%)\end{array}$ & $\begin{array}{c}3 \\
(8,8 \%)\end{array}$ & $\begin{array}{c}3 \\
(8,8 \%)\end{array}$ & & $\begin{array}{l}\text { Кости МРС (15); бусы (9); ритуальное веще- } \\
\text { ство (2); нож (4); оселок (1); перстень (1); } \\
\text { зеркало (2); пряслице (5); кинжал (1); копье } \\
(1) \text {; стрелы (1); фигурка из мела (1); подвес- } \\
\text { ки (3); костяная ложка (2); пряжка (1); крем- } \\
\text { невый отщеп (1) }\end{array}$ \\
\hline $10-14$ & $\begin{array}{c}24 \\
(18,2 \%)\end{array}$ & $\begin{array}{c}10 \\
(41,7 \%)\end{array}$ & $\begin{array}{c}6 \\
(25,0 \%)\end{array}$ & $\begin{array}{c}3 \\
(12,5 \%)\end{array}$ & & $\begin{array}{l}\text { Кости МРС (7); бусы (4); зеркало (4); пряслице } \\
\text { (7); стрелы (5); ритуальное вещество (2); под- } \\
\text { вески (2); веточка коралла (1); костяная ложка } \\
\text { (2); пряжка (1); бронзовый прут (1); нож (3) }\end{array}$ \\
\hline Итого & $\begin{array}{c}132 \\
(100 \%)\end{array}$ & $\begin{array}{c}61 \\
(46,2 \%) \\
\end{array}$ & $\begin{array}{c}13 \\
(9,8 \%) \\
\end{array}$ & $\begin{array}{c}8 \\
(6,1 \%) \\
\end{array}$ & $\begin{array}{c}7 \\
(5,3 \%)\end{array}$ & \\
\hline \multicolumn{7}{|c|}{ Могильник Бережновка } \\
\hline $0-4$ & $\begin{array}{c}19 \\
(61,3 \%) \\
\end{array}$ & $\begin{array}{c}13 \\
(68,4 \% \\
\end{array}$ & $\begin{array}{c}2 \\
(10,5 \%) \\
\end{array}$ & & $\begin{array}{c}1 \\
(5,3 \%) \\
\end{array}$ & $\begin{array}{l}\text { Кости МРС (7); бусы (3); нож (1); ритуаль- } \\
\text { ное вещество (1) }\end{array}$ \\
\hline $5-9$ & $\begin{array}{c}8 \\
(25,8 \%) \\
\end{array}$ & $\begin{array}{c}5 \\
(62,5 \%) \\
\end{array}$ & $\begin{array}{c}1 \\
(12,5 \%) \\
\end{array}$ & $\begin{array}{c}1 \\
(12,5 \%) \\
\end{array}$ & & $\begin{array}{l}\text { Кости МРС (3); бусы (1); копье (1); пряслице } \\
\text { (1) }\end{array}$ \\
\hline $10-14$ & $\begin{array}{c}4 \\
(12,9 \%) \\
\end{array}$ & $\begin{array}{c}3 \\
(75 \%) \\
\end{array}$ & $2(50 \%)$ & $\begin{array}{c}1 \\
(25 \%) \\
\end{array}$ & & Кости МРС (1); бусы (1); пряслице (1) \\
\hline Итого & $\begin{array}{c}31 \\
(100 \%) \\
\end{array}$ & $\begin{array}{c}21 \\
(67,7 \%) \\
\end{array}$ & $\begin{array}{c}5 \\
(16,1 \%) \\
\end{array}$ & $\begin{array}{c}2 \\
(6,45 \%) \\
\end{array}$ & $\begin{array}{c}1 \\
(3,2 \%) \\
\end{array}$ & \\
\hline \multicolumn{7}{|c|}{ Могильник Калиновка } \\
\hline $0-1$ & $\begin{array}{c}8 \\
(21,1 \%)\end{array}$ & & & & & Бусы (1) \\
\hline $1-4$ & $\begin{array}{c}10 \\
(26,3 \%)\end{array}$ & $\begin{array}{c}9 \\
(90,0 \%)\end{array}$ & & & & Кости МРС (1); бусы (3) \\
\hline $5-9$ & $\begin{array}{c}13 \\
(34,2 \%) \\
\end{array}$ & $\begin{array}{c}3 \\
(23,1 \%) \\
\end{array}$ & & & & $\begin{array}{l}\text { Кости МРС (2); бусы (4); подвески (1); пер- } \\
\text { стень (1); зеркало (1); пряслице (2) }\end{array}$ \\
\hline $10-14$ & $\begin{array}{c}7 \\
(18,4 \%)\end{array}$ & $\begin{array}{c}4 \\
(57,1 \%)\end{array}$ & & & & $\begin{array}{l}\text { Кости МРС (3); бусы (2); подвески (2); ве- } \\
\text { точка коралла (1); нож (1); зеркало (2); риту- } \\
\text { альное вещество (1); пряслице (2); стрелы } \\
\text { (1); ложка (1) }\end{array}$ \\
\hline Итого & $\begin{array}{c}38 \\
(100 \%) \\
\end{array}$ & $\begin{array}{c}15 \\
(39,5 \%)\end{array}$ & & & & \\
\hline \multicolumn{7}{|c|}{ Могильник Ковалевка } \\
\hline $0-1$ & $\begin{array}{c}6 \\
(40,0 \%) \\
\end{array}$ & $\begin{array}{c}2 \\
(33,3 \%)\end{array}$ & & $\begin{array}{c}1 \\
(16,7 \%)\end{array}$ & & Кости МРС (1); бусы (1) \\
\hline $1-4$ & $\begin{array}{c}2 \\
(13,3 \%) \\
\end{array}$ & $\begin{array}{c}2 \\
(100 \%) \\
\end{array}$ & & & & Кости МРС (1); нож (1); оселок (1) \\
\hline $5-9$ & $\begin{array}{c}5 \\
(33,4 \%)\end{array}$ & $\begin{array}{c}4 \\
(80,0 \%)\end{array}$ & & $\begin{array}{c}1 \\
(20,0 \%)\end{array}$ & & $\begin{array}{l}\text { Кости МРС (4); бусы (1); пряжка (1); фигур- } \\
\text { ка из мела (1); ритуальное вещество (1); } \\
\text { кинжал (1); пряслице (1); костяная ложка (2) }\end{array}$ \\
\hline $10-14$ & $\begin{array}{c}2 \\
(13,3 \%) \\
\end{array}$ & & & $\begin{array}{c}1 \\
(50,0 \%) \\
\end{array}$ & & Кости МРС (1); зеркало (1); \\
\hline Итого & $\begin{array}{c}15 \\
(100 \%)\end{array}$ & $\begin{array}{c}8 \\
(53,3 \%)\end{array}$ & & $\begin{array}{c}3 \\
(20,0 \%)\end{array}$ & & \\
\hline
\end{tabular}


M.А. Балабанова. Морфология детских захоронений ранних кочевников Нижнего Поволжья

Окончание таблицы 3

\begin{tabular}{|c|c|c|c|c|c|c|}
\hline \multirow{2}{*}{$\begin{array}{l}\text { Воз- } \\
\text { раст- } \\
\text { ная ко- } \\
\text { горта }\end{array}$} & \multirow{2}{*}{$\begin{array}{l}\text { Количество } \\
\text { погребений }\end{array}$} & \multicolumn{4}{|c|}{ Керамика } & \multirow{2}{*}{$\begin{array}{c}\text { Инвентарь } \\
\text { (число погребений с данным инвентарем) }\end{array}$} \\
\hline & & $\begin{array}{l}\text { Лепной } \\
\text { сосуд }\end{array}$ & Кувшин & $\begin{array}{c}\text { Миска / кан- } \\
\text { фар / Ойнохоя } \\
\text { / алебастро- } \\
\text { вый сосуд / } \\
\text { мраморный } \\
\text { сосуд }\end{array}$ & $\begin{array}{l}\text { Куриль- } \\
\text { ница }\end{array}$ & \\
\hline \multicolumn{7}{|c|}{ Могильник Первомайский } \\
\hline $0-1$ & $\begin{array}{c}4 \\
(20,0 \%)\end{array}$ & & $\begin{array}{c}1 \\
(25,0 \%)\end{array}$ & $\begin{array}{c}1 \\
(25,0 \%)\end{array}$ & & \\
\hline $1-4$ & $\begin{array}{c}4 \\
(20,0 \%)\end{array}$ & $\begin{array}{c}1 \\
(25,0 \%)\end{array}$ & $\begin{array}{c}1 \\
(25,0 \%)\end{array}$ & & $\begin{array}{c}2 \\
(50,0 \%)\end{array}$ & $\begin{array}{l}\text { Кости МРС (1); антропоморфная фигурка из } \\
\text { мела (1); ритуальное вещество (1); раковина } \\
\text { (1) }\end{array}$ \\
\hline $5-9$ & $\begin{array}{c}6 \\
(30,0 \%)\end{array}$ & $\begin{array}{c}5 \\
(83,3 \%)\end{array}$ & $\begin{array}{c}2 \\
(33,3 \%)\end{array}$ & $\begin{array}{c}1 \\
(16,7 \%)\end{array}$ & & $\begin{array}{l}\text { Кости МРС (4); бусы (3); подвески (2); нож } \\
\text { (3); зеркало (1); ритуальное вещество (1); } \\
\text { стрелы (1); пряслице (1) }\end{array}$ \\
\hline $10-14$ & $\begin{array}{c}6 \\
(30,0 \%) \\
\end{array}$ & $\begin{array}{c}3 \\
(50,0 \%) \\
\end{array}$ & & & & $\begin{array}{l}\text { Кости МРС (2); нож (1); стрелы (3); прясли- } \\
\text { це (1); ритуальное вещество (1) }\end{array}$ \\
\hline Итого & $\begin{array}{c}20 \\
(100 \%) \\
\end{array}$ & $\begin{array}{c}9 \\
(47,4 \%) \\
\end{array}$ & $\begin{array}{c}4 \\
(21,0 \%) \\
\end{array}$ & $\begin{array}{c}2 \\
(10,5 \%) \\
\end{array}$ & $\begin{array}{c}2 \\
(10,5 \%) \\
\end{array}$ & \\
\hline \multicolumn{7}{|c|}{ Могильник Перегрузное I } \\
\hline $0-1$ & $\begin{array}{c}10 \\
(34,5 \%) \\
\end{array}$ & $\begin{array}{c}3 \\
(30,0 \%) \\
\end{array}$ & & & $\begin{array}{c}1 \\
(10,0 \%) \\
\end{array}$ & Нож (1); ритуальное вещество (1); нож (1) \\
\hline $1-4$ & $\begin{array}{c}11 \\
(37,9 \%)\end{array}$ & $\begin{array}{c}3 \\
(27,3 \%)\end{array}$ & & & $\begin{array}{c}3 \\
(27,3 \%)\end{array}$ & $\begin{array}{l}\text { Кости МРС (3); альчик (1); бусы (5); перстень } \\
(1) \text {; зеркало (1); клык кабана (1); костяная } \\
\text { трубка (1); каменная плитка (1); пряслице (1); } \\
\text { кинжал (1); ритуальное вещество (1) }\end{array}$ \\
\hline $5-9$ & $\begin{array}{c}3 \\
(10,3 \%)\end{array}$ & $\begin{array}{c}2 \\
(66,7 \%)\end{array}$ & & & & $\begin{array}{l}\text { Кости МРС (2); нож (1); оселок (1); кремне- } \\
\text { вый отщеп (1) }\end{array}$ \\
\hline $10-14$ & $\begin{array}{c}5 \\
(17,3 \%)\end{array}$ & & $\begin{array}{c}4 \\
(80,0 \%)\end{array}$ & $\begin{array}{c}1 \\
(20,0 \%)\end{array}$ & & $\begin{array}{l}\text { Кости МРС (2); нож (1); бусы (1); пряжка (1); } \\
\text { зеркало (1); пряслице (3); стрелы (1); брон- } \\
\text { зовый прут (1); костяная ложка (1) }\end{array}$ \\
\hline Итого & $\begin{array}{c}29 \\
(100 \%)\end{array}$ & $\begin{array}{c}8 \\
(27,6 \%) \\
\end{array}$ & $\begin{array}{c}4 \\
(13,8 \%)\end{array}$ & $\begin{array}{c}1 \\
(3,4 \%)\end{array}$ & $\begin{array}{c}4 \\
(13,8 \%)\end{array}$ & \\
\hline
\end{tabular}

Примечание. * Количество погребений без учета данных по могильнику Бережновка.

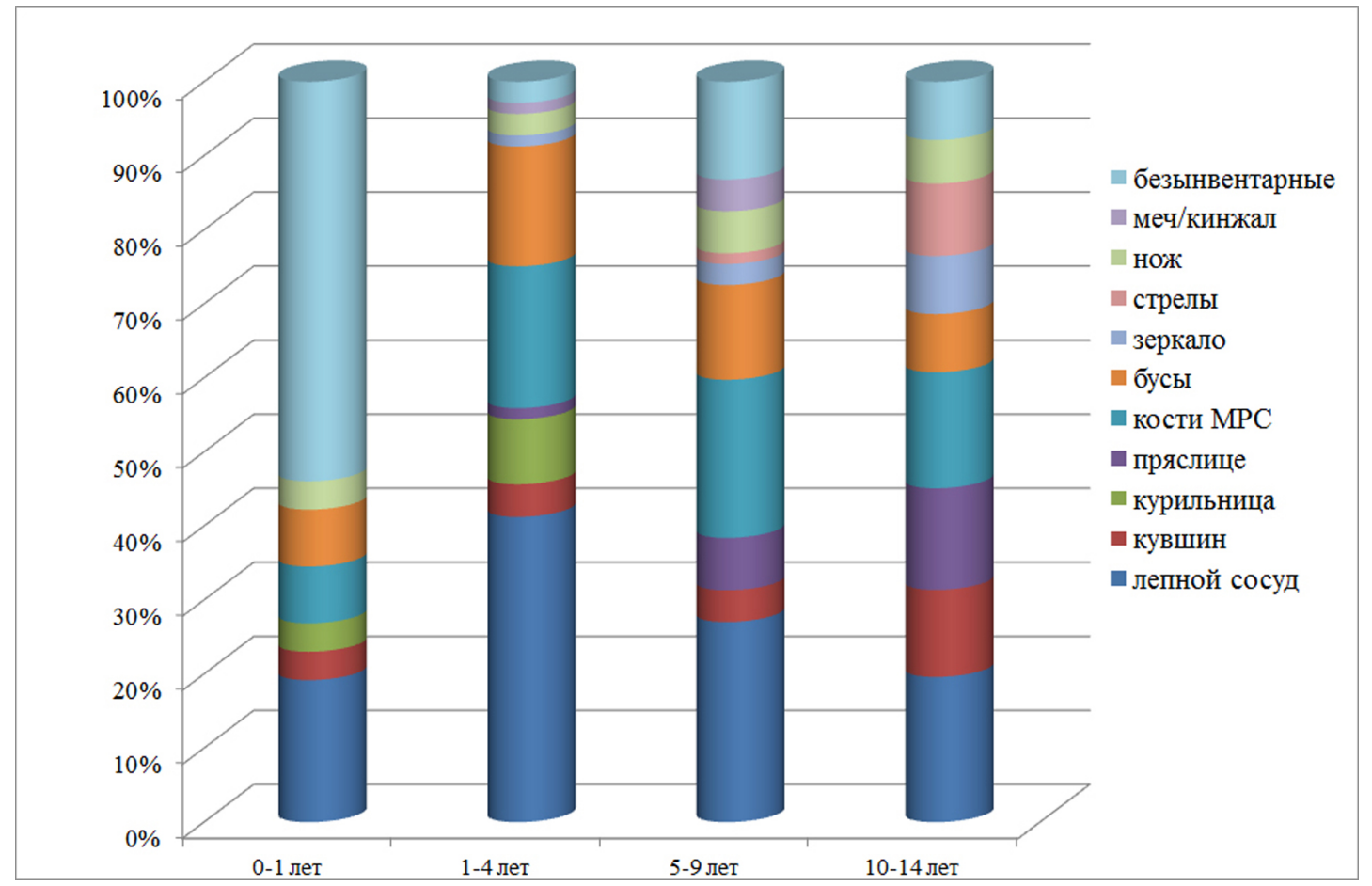

Рис. 6. Предметный комплекс в детских погребениях

Fig. 6. Subject complex in children's burials 


\section{ПРИМЕЧАНИЯ}

${ }^{1}$ Исследование выполнено при финансовой поддержке РФФИ и Администрации Волгоградской области, проект «Палеоантропология детской части населения Нижнего Поволжья» № 15-46-02056.

2 За последние десятилетия в результате антропологического изучения раннесарматских материалов была составлена база данных по полу и возрасту погребенных, что позволяет детализировать детский возраст при исследованиях подобного характера.

\section{СПИСОК ЛИТЕРАТУРЫ}

Балабанова М. А., 2009. Хронологические особенности половозрастной структуры сарматских групп Нижнего Поволжья // Вестник Волгоградского государственного университета. Серия 4, История. Регионоведение. Международные отношения. № 1 (15). С. 5-12.

Балабанова М. А., Перерва Е. В., Клепиков В. М., Кривошеев М. В., Демкин В. А., Ельцов М. В., Скрипкин А. С., Удальцов С. Н., Яворская Л. В., Дьяченко А. Н., 2014. Курганный могильник Перегрузное I: результаты междисциплинарных исследований. Волгоград : Изд-во Волгогр. фил. РАНХиГС. 368 с.

Балабанова М. А., Клепиков В. М., Коробкова Е. А., Кривошеев М. В., Перерва Е. В., Скрипкин А. С., 2015. Половозрастная структура сарматского населения Нижнего Поволжья: погребальная обрядность и антропология. Волгоград : Изд-во Волгогр. фил. РАНХиГС. 272 c.

Батиева Е. Ф., 2011. Население Нижнего Дона в IX в. до н.э. - IV в. н.э. (палеоантропологическое исследование). Ростов н/Д : Изд-во ЮНЦРАН. $160 \mathrm{c}$.

Берсенева Н. А., Гильмитдинова А. Х., 2013. Детские погребения ранних кочевников Южного Урала (IV-II вв. до н.э.) // Вестник археологии, антропологии и этнографии. № 2 (21). C. $36-44$.

Бужилова А. П., 1998. Палеопатология в биоархеологических реконструкциях // Историческая экология человека. Методика биологических исследований. М. : Старый Сад. С. 87-147.

Гинзбург В. В., 1959. Этногенетические связи древнего населения Сталинградского Заволжья (по материалам Калиновского могильника) // Материалы и исследования по археологии СССР. № 60. Древности Нижнего Поволжья. Т. І. М. : Изд-во Академии наук CCCP. C. 524-594.
Демиденко С. В., Демиденко Ю. В., Мамонтов В. И., 2006. Курганный могильник Первомайский I // Нижневолжский археологический вестник. Вып. 8. С. 187-218.

Добровольская М. В., 2005. Человек и его пища. М. : Научный мир. 368 с.

Клепиков В. М., 2002. Сарматы Нижнего Поволжья в IV-III вв. до н.э. Волгоград : Изд-во ВолГУ. 216 с.

Ллойд де Моз, 2000. Психоистория. Ростов н/Д : Феникс. 512 с.

Мамонтов В. И., 2000. Древнее население левобережья Дона (по материалам курганного могильника Первомайский VII). Волгоград : Изд-во ВолГУ. 150 с.

Мыськов Е. П., Лапшин А. С., Кияшко А. В., 2006. Раскопки курганных могильников Октябрьский VI, Октябрьский VII и Ковалевка в Октябрьском районе Волгоградской области // Архив ВОКМ. № 225.

Сергацков И. В., 2000. Сарматские курганы на Иловле. Волгоград : Изд-во ВолГУ. 396 с.

Синицын И. В., 1959. Археологические исследования Заволжского отряда (1951-1953 гг.) // Материалы и исследования по археологии СССР. № 60. Древности Нижнего Поволжья. Т. І. М. : Изд-во Академии наук СССР. С. 39-205.

Синицын И. В., 1960. Древние памятники в низовьях Еруслана (по раскопкам 1954-1955 гг.) // Материалы и исследования по археологии СССР. № 78. Древности Нижнего Поволжья. Т. II. М. : Изд-во Академии наук СССР. C. $10-168$.

Скрипкин А. С., 1997. Анализ сарматских погребальных памятников III-I вв. до н.э. // Статистическая обработка погребальных памятников Азиатской Сарматии. Вып. II. Раннесарматская культура (IV-I вв. до н.э.). М. : ИА РАН. C. $131-212$.

Туаева Н. Ю., 2008. Социализация детей и юношества в традиционном осетинском обществе: вторая половина XIX - начало XX века : автореф. дис. ... канд. ист. наук. Владикавказ. $21 \mathrm{c}$.

Фирштейн Б. В., 1970. Сарматы Нижнего Поволжья в антропологическом освещении // Антропологические данные к вопросу о великом переселении народов. Авары и сарматы. Л. : Наука. С. 69-201.

Шилов В. П., 1959. Калиновский курганный могильник // Материалы и исследования по археологии СССР. № 60. Древности Нижнего Поволжья. Т. І. М. : Изд-во Академии наук СССР. C. 323-523.

Weiss K., 1973. Demographic models for anthropology. Memoirs of the Society for American 
Archeology, memoir 27 // American antiquity. Vol. 38. № 2. Part 2. 186 p.

\section{REFERENCES}

Balabanova M.A., 2009. Chronological features of the sex-age structure of the Sarmatian groups of the Lower Volga region. Science Journal of Volgograd State University. History. Area Studies. International Relations, vol. 15, no. 1, pp. 5-12. (in Russian).

Balabanova M.A., Pererva E.V., Klepikov V.M., Krivosheev M.V., Demkin V.A., Yeltsov M.V., Skripkin, A.S., Udaltsov S.N., Yavorskaya L.V., Dyachenko A.N., 2014. Peregruznoe I burial mound: results of the interdisciplinary research. Volgograd, Izd-vo Volgogr. fil. RANKhiGS. 368 p. (in Russian).

Balabanova M.A., Klepikov V.M., Korobkova E.A., Krivosheev M.V., Pererva E.V., Skripkin A.S., 2015. Sex-age structure of the Sarmatian population of the Lower Volga region: funeral rites and anthropology. Volgograd, Izd-vo Volgogr. fil. RANKhiGS. 272 p. (in Russian).

Batieva E.F., 2011. The population of the Lower Don in the $9^{\text {th }}$ century $B C-4^{\text {th }}$ century $A D$ (paleoanthropological study). Rostov-on-Don, Izd-vo YuNTs RAN. 160 p. (in Russian).

Berseneva N.A., Gilmitidinova A.Kh., 2013. Children's burials of the early nomads of the Southern Urals $\left(4^{\text {th }}-2^{\text {nd }}\right.$ centuries BC). Bulletin of Archaeology, Anthropology and Ethnography, no. 2 (21), pp. 36-44. (in Russian).

Buzhilova A.P., 1998. Paleopathology in bioarchaeological reconstructions. Historical ecology of man. Methodology of biological research. Moscow, Staryy sad Publ.,pp. 87-147. (in Russian).

Ginzburg V.V., 1959. Ethnogenetic connections of the ancient population of the Stalingrad TransVolga: (based on materials from the Kalinovsky burial mound). Materials and research on archaeology of the USSR, no. 60. Moscow, Izd-vo AN SSSR, pp. 524-594. (in Russian).

Demidenko S.V., Demidenko Yu.V., Mamontov V.I., 2006. Pervomayskiy I burial mound. The Lower Volga Archaeological Bulletin, iss. 8, pp. 187218. (in Russian).

Dobrovolskaya M.V., 2005. Man and his food. Moscow, Nauchnyy mir Publ. 368 p. (in Russian).
Klepikov V.M., 2002. Sarmatians of the Lower Volga region in the $4^{\text {th }}-3^{\text {rd }} c$. BC. Volgograd, Izd-vo VolGU. 216 p. (in Russian).

Lloyd de Mause, 2000. Psycho-history. Rostov-onDon, Feniks Publ. 512 p.

Mamontov V.I., 2000. The ancient population of the left bank of the Don river (based on the materials of Pervomayskiy VII burial mound). Volgograd, Izd-vo VolGU. 150 p. (in Russian).

Myskov E.P., Lapshin A.S., Kiyashko A.V., 2006. Excavations of burial mounds of Oktyabrsky VI, Oktyabrsky VII and Kovalevka in the Oktyabrsky district of the Volgograd region. Archive of VOKM, no. 225. (in Russian).

Sergatskov I.V., 2000. Sarmatian barrows on the Ilovlya river. Volgograd, Izd-vo VolGU. 396 p. (in Russian).

Sinitsyn I.V., 1959. Archaeological research of the Zavolzhsky detachment (1951-1953). Materials and research on archaeology of the USSR, no. 60. Moscow, Izd-vo Academii Nauk SSSR, pp. 39-205. (in Russian).

Sinitsyn I.V., 1960. Ancient monuments in the lower reaches of Eruslan (excavations 1954-1955). Materials and research on archaeology of the USSR, no. 78. Moscow, Izd-vo AN SSSR, pp. 10168. (in Russian).

Skripkin A.S., 1997. Analysis of Sarmatian funerary monuments of the $3^{\text {rd }}-1^{\text {st }}$ centuries BC. Statistical processing of funerary monuments of Asian Sarmatia. Iss. II. Early Sarmatian culture $\left(4^{\text {th }}-1^{\text {st }}\right.$ centuries BC). Moscow, Izd-vo IA RAN, pp. 131-212. (in Russian).

Tuaeva N.Yu., 2008. Socialization of children and youth in the traditional Ossetian society: second half of $19^{\text {th }}$ - early $20^{\text {th }}$ century. Cand. hist. sci. abs. diss. Vladikavkaz. 21 p.

Firshteyn B.V., 1970. Sarmatians of the Lower Volga region from the anthropological viewpoint. Anthropological data on the issue of the great migration of peoples. Avars and Sarmatians. Leningrad, Nauka Publ.,pp. 69-201. (in Russian).

Shilov V.P., 1959. Kalinovsky burial mound. Materials and research on archaeology of the USSR, no. 60. Moscow, Izd-vo AN SSSR, pp. 323-523. (in Russian).

Weiss K., 1973. Demographic models for anthropology. Memoirs of the Society for American Archeology, memoir 27. American antiquity, vol. 38, no. 2, part 2.186 p. 
M.A. Balabanova. Morphology of Child Burials of Early Nomads in the Lower Volga Region

\section{Information about the Author}

Mariya A. Balabanova, Doctor of Sciences (History), Head of Department of Archaeology, Foreign History and Tourism, Volgograd State University, Prosp. Universitetsky, 100, 400062 Volgograd, Russian Federation,mary_balabanova@mail.ru, adsi@volsu.ru.

\section{Информация об авторе}

Мария Афанасьевна Балабанова, доктор исторических наук, заведующая кафедрой археологии, зарубежной истории и туризма, Волгоградский государственный университет, просп. Университетский, 100, 400062 г. Волгоград, Российская Федерация, mary_balabanova@mail.ru, adsi@volsu.ru. 